\title{
Ileal digestibility of amino acids in maize gluten feed for pigs *
}

\author{
C. Jondreville', J. van den Broecke ${ }^{2}$, F.Grosjean', S. Van \\ Cauwenberghe $^{2}$ and F. Gâtel ${ }^{1}$
}

\author{
'Technical Institute for Cereals and Forage \\ 3 rue des Frères Périer, 75116 Paris, France \\ ${ }^{2}$ Eurolysine \\ 153 rue de Courcelles, 75817 Paris Cedex 17, France
}

(Received 28 May 1999; accepted 13 January 2000)

\begin{abstract}
Seven batches of maize gluten feed (MGF) were studied for their protein and amino acid standardised ileal digestibility (SID). Each batch was tested on four castrated male pigs Large White (LW) or (LW x Landrace - L) x (LW x Piétrain - P) weighing between 42 and $61 \mathrm{~kg}$, and fitted with an end-to-end ileo-rectal anastomosis. In all batches, lysine, threonine, cystine, tryptophan, aspartic acid and glycine displayed the lowest SID values (on average 62.9, 69.6, 66.7, 64.1, 69.7 and 62.4\%, respectively). On the contrary, methionine, arginine, leucine, tyrosine and phenylalanine were among the most digestible amino acids and their average SID reached 84.8, 85.6, 82.3, 83.2 and 82.7\%, respectively. Significant differences between batches of MGF appeared for SID of most amino acids. SID of most amino acids decreased as the proportion of $\mathrm{N}$ bound to the NDF residue increased.
\end{abstract}

KEY WORDS: maize gluten feed, ileal digestibility, amino acids, pigs

\section{INTRODUCTION}

Maize gluten feed (MGF), by-product of maize starch extraction, is made of the fibrous part of the maize grain and of maize steep liquor, approximately in the proportion of 3 to 1. Although in small proportion, maize germ meal, the chemical

* Part of the results were obtained with the financial support of the Ministère français de l'Education Nationale, de l'Enseignement Supérieur et de la Recherche (ACTA programme) and the European Commission (CAMAR CT 91-0112) 
characterisation of which is close to the one of MGF, is sometimes added to the final product. MGF being the result of a complex industrial process, its composition and its feeding value may be variable. Although this by-product is widely used in pig feeding, only few values relative to its nitrogen $(\mathrm{N})$ and amino acid (AA) ileal digestibility are available in literature (Mariscal-Landin, 1992). The aim of this study, part of a more extensive work on AA ileal digestibility in pig feeds (Jondreville et al., 1995), was to measure the $\mathrm{N}$ and AA standardised ileal digestibility in MGF, to evaluate the extent of its variability and to assess the relevance of analytical criteria for its prediction.

\section{MATERIAL AND METHODS}

\section{Animals}

Castrated male pigs pure bred Large White or (Large White $\mathrm{x}$ Landrace) $\mathrm{x}$ (Large White $x$ Piétrain) were surgically prepared with an end-to-end ileo-rectal anastomosis at a liveweight of 25 to $30 \mathrm{~kg}$ according to the method described by Picard et al. (1984) and Laplace et al. (1989). The experiments lasted from 1991 to 1993 and required the preparation of 16 growing pigs used in trials as four independent groups of four animals. Each batch of MGF was tested on four animals of only one group, at one period, both selected at random (Table 1). Therefore the reliability of our data was based on the initial assumption of the absence of effects, not only of pig ageing or liveweight, but also of other group characteristics on AA ileal digestibility.

Table 1

Distributionhes of the batches of maize gluten feed among groups of pigs, number of pigs ( $\mathrm{n}$ ), average feeding level (FL, g DM/kg LW $\left.{ }^{0.75}\right)$ and liveweight $(\mathrm{LW}, \mathrm{kg})$

\begin{tabular}{|c|c|c|c|c|c|c|c|}
\hline & MGF1 & MGF2 & MGF3 & MGF4 & MGF5 & MGF6 & MGF7 \\
\hline Group & 1 & 1 & 1 & 1 & 2 & 3 & 4 \\
\hline $\mathrm{n}$ & 4 & 4 & 4 & 4 & 3 & 4 & 4 \\
\hline FL & $79 \quad(3)^{1}$ & $76 \quad(4)$ & 80 (1) & $79 \quad(4)$ & 74 & $73 \quad(3)$ & 79 (3) \\
\hline LW & $59 \quad(5)$ & 61 (9) & $59 \quad(8)$ & $59 \quad(7)$ & $46 \quad(2)$ & 42 (2) & 49 (1) \\
\hline
\end{tabular}

standard deviation

As described by Green et al. (1987), each test consisted of two phases: an adaptation period of five days followed by a two-day continuous collection period. This combination of the adaptation and collection periods was among those which allowed the most accurate measurement of $\mathrm{N}$ excreted by pigs fitted with an end- 
to-end ileo-rectal anastomosis (Mariscal-Landin et al., 1995). Twice a day, just after meal, digesta were transferred from cages to a refrigerator and kept at $4^{\circ} \mathrm{C}$. At the end of the collection period, the digesta of each pig were homogenised and two samples were taken: one was oven-dried $\left(80^{\circ} \mathrm{C}\right.$ for $\left.72 \mathrm{~h}\right)$ for dry matter determination and the other one was freeze-dried prior to analysis.

\section{Feedstuffs, experimental diets and feeding}

Seven commercial batches of maize gluten feed (MGF1 to MGF7) were selected to be representative for feed used in Europe. MGF6 originated from USA, whereas the other ones originated from European maize starch extraction plants. Each sample of MGF was ground in a hammer mill fitted with a $2 \mathrm{~mm}$ screen. Except for MGF4, each of them was mixed with maize starch and sucrose (1:1) and a mineral and vitamin concentrate $(55 \mathrm{~g} / \mathrm{kg}$ diet $)$, so that the $\mathrm{N}$ content of the diets was around $31 \mathrm{~g} / \mathrm{kg}$ DM (Table 2). Because of its low $\mathrm{N}$ content, MGF4 was only mixed with the mineral and vitamin concentrate.

Animals were fed twice daily ( 8 a.m. and 4 p.m.) a diet in meal form mixed with water $(1: 2, \mathrm{v} / \mathrm{v})$ at the time of feeding. Drinking water was continuously

Table 2

Chemical composition of maize gluten and formulation of diets

\begin{tabular}{lccrrrrr}
\hline & MGF1 & MGF2 & MGF3 & MGF4 & MGF5 & MGF6 & MGF7 \\
\hline Chemical composition of & MGF, g/kg DM & & & & & \\
N & 35.0 & 36.8 & 39.2 & 31.8 & 37.9 & 34.9 & 38.4 \\
Fat & 33.1 & 22.5 & 28.2 & 40.9 & 21.2 & 33.5 & 49.5 \\
CF & 83.2 & 77.8 & 92.7 & 75.0 & 79.3 & 93.9 & 80.6 \\
Ash & 65.0 & 55.2 & 63.3 & 61.4 & 54.7 & 109.5 & 83.1 \\
NDF & 388.0 & 378.0 & 413.7 & 389.2 & 304.4 & 384.7 & 366.1 \\
ADF & 98.4 & 90.4 & 105.6 & 95.0 & 92.8 & 133.9 & 94.0 \\
ADL & 12.4 & 7.4 & 10.9 & 12.2 & 8.2 & 24.4 & 9.3 \\
N-NDF & 8.0 & 3.5 & 6.2 & 11.0 & 3.9 & 7.3 & 4.1 \\
Starch & 256.6 & 235.6 & 188.7 & 355.7 & 232.4 & 154.2 & 202.1 \\
Formulation of dicts, g/kg DM & & & & & & \\
MGF & 886 & 855 & 813 & 945 & 849 & 864 & 772 \\
Starch/sucr. & 59 & 90 & 132 & - & 96 & 81 & 173 \\
Min./vit. conc. & 55 & 55 & 55 & 55 & 55 & 55 & 55 \\
\hline
\end{tabular}

1 maize starch and sucrose mixture (1:1)

2 the mineral and vitamin concentrate provided per $\mathrm{kg} \mathrm{DM}$ feed: $303 \mathrm{mg} \mathrm{MgCl} 6 \mathrm{H} 2 \mathrm{O}, 303 \mathrm{mg} \mathrm{KCl}$, $8437 \mathrm{mg} \mathrm{NaCl}, 22000 \mathrm{mg} \mathrm{NaHCO}, 9548 \mathrm{mg} \mathrm{CaHPO}, 10849 \mathrm{mg} \mathrm{CaCO}, 512 \mathrm{mg} ; \mathrm{FeSO}_{4} 7 \mathrm{H}_{2} \mathrm{O}$, $303 \mathrm{mg} \mathrm{ZnSO}_{4} 1 \mathrm{H}_{2} \mathrm{O}, 80 \mathrm{mg} \mathrm{CuSO}_{4} 5 \mathrm{H}_{2} \mathrm{O}, 121 \mathrm{mg} \mathrm{MnSO} \mathrm{m}_{4} 1 \mathrm{H}_{2} \mathrm{O}, 5 \mathrm{mg} \mathrm{CoCO}, 2 \mathrm{mg} \mathrm{Ca}\left(\mathrm{IO}_{3}\right)_{2}$. 27500 IU vit. A, 2200 IU vit. D3, $4070 \mathrm{IU}$ vit. E, $21 \mathrm{mg}$ vit. $\mathrm{K} 3,6 \mathrm{mg}$ vit. B1, $14 \mathrm{mg}$ vit. B2, $13 \mathrm{mg}$ vit. B6, $51 \mathrm{mg}$ vit. PP, $80 \mathrm{mg}$ vit. C, $1 \mathrm{mg}$ folic acid, $70 \mathrm{mg}$ vit. B12,0.03 mg biotin, $30 \mathrm{mg}$ vit. B3, $804 \mathrm{mg}$ choline, $50 \mathrm{mg}$ carbadox 
available. The feeding scale was set at $90 \mathrm{~g}$ meal per $\mathrm{kg}$ metabolic weight (liveweight $t^{0.75}$ ), i.e., taking into account the dry matter concentration in our maize gluten feed based diets, around $76 \mathrm{~g}$ dry matter ingested per $\mathrm{kg}$ metabolic weight. Every week, the feed supply was individually adjusted, based on weighings at four-week intervals and expected increase in liveweight between weighings.

\section{Chemical analysis}

All the chemical determinations were performed in duplicate. Each batch of MGF, each diet and each sample of digesta was analysed for $\mathrm{N}$ and AA. The $\mathrm{N}$ content was measured by the Kjeldahl method (AFNOR, 1977a), with a Kjel-foss automatic apparatus (Foss-Electric, Denmark). AA were determined on a Beckman $6300 \mathrm{AA}$ analyser after $23 \mathrm{~h}$ hydrolysis in $\mathrm{HCl} 6 \mathrm{~N}$ at $110^{\circ} \mathrm{C}$ (AFNOR, 1993a). Methionine and cystine were determined after oxidation with performic acid. Tryptophan was determined by HPLC followed by fluorometric detection (Kontron Instrument, France). Hydrolysis was carried out in alkaline solution of $\mathrm{Ba}(\mathrm{OH})_{2}$ at $125^{\circ} \mathrm{C}$ for $16 \mathrm{~h}$ (Landry and Delhaye, 1992).

The dry matter (DM) content of each batch of MGF was determined by drying to constant weight at $103^{\circ} \mathrm{C}$ (AFNOR, 1976). For the determination of ash content, samples were placed at $550^{\circ} \mathrm{C}$ for $8 \mathrm{~h}$ (AFNOR, 1977b). Neutral detergent fibre (NDF), acid detergent fibre (ADF) and acid detergent lignin (ADL) determinations were sequentially carried out following the van Soest et al. (1991) method, and crude fibre (CF) according to the Weende method (AFNOR, 1993b), by means of a Fibertec system (Tecator, Sweden). The concentration of $N$ in the NDF residue (N-NDF) was evaluated by the successive analysis of NDF and N, as described above. Fat content was measured without hydrolysis prior to analysis (OJEC, 1984), by means of a Soxtherm apparatus (Gerhardt, Germany). According to the Ewers method (OJEC, 1980), starch was hydrolysed by hot hydrochloric acid before measurement of specific rotation (POL.400, Isabiologie, France).

\section{Digestibility calculation}

Apparent ileal digestibility (AID) was calculated from $\mathrm{N}$ and AA concentrations in the diets and in the ileal digesta. Standardised ileal digestibility (SID) was recalculated, according to the following formula, as suggested by Low (1982):

$$
\text { SID AA }(\%)=\text { AID AA }(\%)+\frac{\text { basal endogenous AA }(g / k g ~ D M I) \times 100}{\text { dietary AA }(g / k g ~ D M)}
$$

For this correction, assumption was made that the basal endogenous losses were in constant proportion to the amount of dry matter ingested (DMI). The basal en- 
dogenous output was previously determined in our laboratory (unpublished results), in 20 replicates, on pigs weighing on average $70 \mathrm{~kg}$, prepared and managed according to the above described procedure, and fed a protein-free diet made of maize starch (580 g per $\mathrm{kg}$ ), sugar ( $300 \mathrm{~g}$ per $\mathrm{kg}$ ), wood cellulose $(35 \mathrm{~g}$ per $\mathrm{kg}$ ), soya oil ( $30 \mathrm{~g}$ per $\mathrm{kg})$ and a mineral and vitamin concentrate $(55 \mathrm{~g}$ per $\mathrm{kg})$. The values of basal endogenous losses are given in Table 4.

\section{Data analyses}

The effect of the batch of MGF (B) on N and AA SID was analysed using the pig liveweight $(\mathrm{LW})$ as covariate; the $\mathrm{LWxB}$ interaction also was tested. The introduction of LW in the model aimed at checking the absence of its effect on SID. However, the effect of group of pigs could not be tested independently of the batch of MGF.

Attempts for prediction of $\mathrm{N}$ and AA SID were made through regressions of the SID values on the chemical characteristics of the diets ( $/ \mathrm{kg} \mathrm{DM}$ ) and on the ratios of the analytical data to the AA concentrations, as suggested by Sève et al. (1994). The analyses were performed using the MINITAB statistical software (MINITAB, 1996), by means of the GLM procedure, for the analyses of variance, and by means of the STEPWISE procedure, for the regression analyses.

\section{RESULTS}

For MGF5, digestibility was calculated on three replicates only because of the death of one pig during experiments (Table 1). On an average the level of feeding of pigs ranged from 73 to $80 \mathrm{~g} \mathrm{DM} / \mathrm{kg} \mathrm{LW}{ }^{0.75}$. The average liveweight of pigs fed the different batches of MGF ranged from 42 to $61 \mathrm{~kg}$.

\section{Composition of $M G F$}

The composition of each batch of MGF is given in Tables 2 and 3. The starch, ash and fat concentrations roughly doubled from MGF6 to MGF4, from MGF5 to MGF6 and from MGF5 to MGF7 and MGF4, respectively. The $\mathrm{N}$ and NDF concentrations were less variable as they increased by $23 \%$ from MGF4 to MGF3 and by $36 \%$ from MGF5 to MGF3, respectively. Except for CF and ADF ( $r=0.83$, $\mathrm{P}<0.05)$, ash and ADF $(\mathrm{r}=0.85, \mathrm{P}<0.05)$, and $\mathrm{N}$ and $\mathrm{N}-\mathrm{NDF}(\mathrm{r}=-0.83, \mathrm{P}<0.05)$, the analytical criteria were not correlated together. Particularly, the proportion of ADF in NDF was variable as it was around 24 to $26 \%$ in all batches except in MGF5 and MGF6, the ADF content of which reached 30 and $35 \%$ of the NDF, respectively. 
Table 3

Amino acid composition of maize gluten feed protein, g/16g N

\begin{tabular}{lrrrrrrr}
\hline & MGF1 & MGF2 & MGF3 & MGF4 & MGF5 & MGF6 & MGF7 \\
\hline EAA & 74.5 & 72.4 & 72.4 & 76.4 & 74.3 & 70.8 & 71.8 \\
Lys & 3.3 & 2.6 & 3.1 & 3.8 & 2.9 & 3.2 & 2.4 \\
Thr & 3.4 & 3.1 & 3.3 & 3.4 & 3.3 & 3.2 & 3.4 \\
Met & 1.8 & 1.6 & 1.8 & 1.9 & 1.7 & 1.5 & 1.7 \\
Cys & 1.8 & 2.1 & 1.8 & 1.5 & 2.0 & 1.6 & 2.0 \\
Trp & 0.8 & 0.6 & 0.7 & 1.0 & 0.5 & 0.7 & 0.4 \\
Ala & 6.4 & 7.1 & 5.8 & 6.0 & 6.1 & 5.1 & 7.2 \\
Arg & 4.5 & 4.5 & 5.3 & 5.6 & 4.7 & 5.2 & 3.0 \\
Asp & 5.6 & 4.8 & 5.7 & 6.5 & 4.9 & 6.0 & 4.8 \\
Glu & 13.7 & 14.4 & 13.3 & 13.3 & 15.0 & 14.2 & 14.2 \\
Gly & 4.4 & 3.9 & 4.2 & 4.7 & 3.8 & 4.0 & 3.7 \\
His & 2.8 & 2.7 & 2.8 & 2.7 & 2.6 & 2.7 & 3.2 \\
Ile & 3.1 & 2.9 & 2.9 & 3.3 & 3.0 & 3.1 & 2.8 \\
Leu & 8.1 & 8.6 & 7.3 & 7.5 & 8.8 & 6.8 & 9.1 \\
Phe & 3.7 & 3.2 & 3.3 & 3.8 & 3.7 & 3.3 & 3.4 \\
Ser & 4.2 & 4.0 & 4.1 & 4.3 & 4.2 & 3.9 & 4.1 \\
Tyr & 2.3 & 2.3 & 2.5 & 2.2 & 2.8 & 2.2 & 2.2 \\
Val & 4.5 & 4.1 & 4.5 & 4.7 & 4.2 & 4.1 & 4.2 \\
\hline
\end{tabular}

I sum of all amino acids

Glutamic acid displayed the highest concentration, followed by leucine, alanine, arginine and aspartic acid, whereas tryptophan content was the lowest, followed by methionine and cystine. There was a relationship between N-NDF and the AA profile of protein: the proportion of lysine, tryptophan, aspartic acid and glycine in protein tended to increase with $\mathrm{N}-\mathrm{NDF}(\mathrm{r}=0.93,0.95,0.95$ and $0.93 ; \mathrm{P}<0.01$, respectively), whereas the proportion of cystine and glutamic acid tended to decrease $(r=-0.91, P<0.01$ and $r=-0.76 ; P<0.05$, respectively).

\section{Standardised ileal digestibility}

The results of the analysis of variance and the SID values are presented in Table 4. The LWxB interaction was significant $(\mathrm{P}<0.05)$ for phenylalanine and tyrosine: the digestibility of these two AA increased with the pig liveweight in MGF2, whereas it was independent of the pig liveweight in the other batches. As the interaction LWxB was significant for these two AA only, the results presented are relative to the model without interaction. No effect of the pig liveweight was detected, whereas the batch of MGF had a significant effect on the digestibility of $\mathrm{N}$ and most AA except for threonine, arginine, glutamic acid and glycine. 
Table 4 Effects of pig liveweight (LW) and batch of maize gluten feed on nitrogen and amino acid standardised ileal digestibility

\begin{tabular}{|c|c|c|c|c|c|c|c|c|c|c|}
\hline & MGF1 & MGF2 & MGF3 & MGF4 & MGF5 & MGF6 & MGF7 & $\begin{array}{c}\mathrm{P}^{2} \\
\mathrm{LW}\end{array}$ & $\begin{array}{c}\mathrm{P}^{2} \\
\text { Batch }\end{array}$ & r.s.d. ${ }^{3}$ \\
\hline $\mathrm{N}$ & $\begin{array}{l}61.8 \\
(3.1)^{4}\end{array}$ & $\begin{array}{c}68.3 \\
(2.0)\end{array}$ & $\begin{array}{l}63.4 \\
(2.4)\end{array}$ & $\begin{array}{l}62.2 \\
(4.2)\end{array}$ & $\begin{array}{l}70.3 \\
(1.1)\end{array}$ & $\begin{array}{l}69.4 \\
(2.4)\end{array}$ & $\begin{array}{l}74.8 \\
(3.7)\end{array}$ & NS & $* *$ & 3.0 \\
\hline Lys & $\begin{array}{l}62.4 \\
(2.6)\end{array}$ & $\begin{array}{l}65.4 \\
(2.6)\end{array}$ & $\begin{array}{l}59.9 \\
(1.2)\end{array}$ & $\begin{array}{l}57.7 \\
(3.7)\end{array}$ & $\begin{array}{c}65.9 \\
(0.6)\end{array}$ & $\begin{array}{l}64.7 \\
(3.1)\end{array}$ & $\begin{array}{l}64.6 \\
(5.9)\end{array}$ & NS & $*$ & 3.4 \\
\hline Thr & $\begin{array}{l}70.1 \\
(4.6)\end{array}$ & $\begin{array}{l}71.9 \\
(1.8)\end{array}$ & $\begin{array}{c}68.8 \\
(1.2)\end{array}$ & $\begin{array}{l}68.8 \\
(4.3)\end{array}$ & $\begin{array}{c}68.1 \\
(0.5)\end{array}$ & $\begin{array}{l}68.3 \\
(2.2)\end{array}$ & $\begin{array}{l}71.1 \\
(5.1)\end{array}$ & NS & NS & 3.4 \\
\hline Met & $\begin{array}{l}80.1 \\
(3.0)\end{array}$ & $\begin{array}{l}85.0 \\
(1.1)\end{array}$ & $\begin{array}{l}86.1 \\
(2.5)\end{array}$ & $\begin{array}{l}82.5 \\
(4.0)\end{array}$ & $\begin{array}{l}87.8 \\
(2.3)\end{array}$ & $\begin{array}{c}83.3 \\
(3.1)\end{array}$ & $\begin{array}{l}89.0 \\
(3.6)\end{array}$ & NS & $*$ & 3.0 \\
\hline Cys & $\begin{array}{l}63.0 \\
(6.2)\end{array}$ & $\begin{array}{l}69.4 \\
(3.9)\end{array}$ & $\begin{array}{l}62.0 \\
(1.6)\end{array}$ & $\begin{array}{l}60.4 \\
(1.6)\end{array}$ & $\begin{array}{l}71.1 \\
(4.9)\end{array}$ & $\begin{array}{l}69.3 \\
(4.2)\end{array}$ & $\begin{array}{l}71.6 \\
(9.4)\end{array}$ & NS & $*$ & 5.1 \\
\hline Trp & $\begin{array}{l}59.2 \\
(3.9)\end{array}$ & $\begin{array}{l}65.0 \\
(3.6)\end{array}$ & $\begin{array}{l}61.3 \\
(2.9)\end{array}$ & $\begin{array}{l}59.9 \\
(4.6)\end{array}$ & $\begin{array}{l}64.8 \\
(2.8)\end{array}$ & $\begin{array}{l}65.9 \\
(2.4)\end{array}$ & $\begin{array}{l}72.8 \\
(4.5)\end{array}$ & NS & $* *$ & 3.7 \\
\hline Ala & $\begin{array}{l}75.9 \\
(1.7)\end{array}$ & $\begin{array}{l}82.8 \\
(1.6)\end{array}$ & $\begin{array}{l}78.3 \\
(1.3)\end{array}$ & $\begin{array}{l}75.0 \\
(2.1)\end{array}$ & $\begin{array}{l}81.5 \\
(0.2)\end{array}$ & $\begin{array}{l}77.4 \\
(1.8)\end{array}$ & $\begin{array}{c}83.4 \\
(3.0)\end{array}$ & NS & $* * *$ & 1.9 \\
\hline Arg & $\begin{array}{l}86.7 \\
(1.6)\end{array}$ & $\begin{array}{l}86.7 \\
(3.3)\end{array}$ & $\begin{array}{l}83.4 \\
(2.4)\end{array}$ & $\begin{array}{l}86.5 \\
(1.3)\end{array}$ & $\begin{array}{l}87.0 \\
(2.0)\end{array}$ & $\begin{array}{l}82.9 \\
(1.9)\end{array}$ & $\begin{array}{l}86.2 \\
(3.6)\end{array}$ & NS & NS & 2.5 \\
\hline Asp & $\begin{array}{l}67.5 \\
(3.5)\end{array}$ & $\begin{array}{l}73.0 \\
(2.1)\end{array}$ & $\begin{array}{l}69.5 \\
(1.1)\end{array}$ & $\begin{array}{l}65.7 \\
(3.5)\end{array}$ & $\begin{array}{l}72.9 \\
(1.1)\end{array}$ & $\begin{array}{l}70.1 \\
(2.3)\end{array}$ & $\begin{array}{l}69.4 \\
(4.6)\end{array}$ & NS & $*$ & 3.0 \\
\hline Glu & $\begin{array}{l}76.8 \\
(2.0)\end{array}$ & $\begin{array}{l}79.6 \\
(1.8)\end{array}$ & $\begin{array}{l}75.8 \\
(0.9)\end{array}$ & $\begin{array}{l}77.0 \\
(2.0)\end{array}$ & $\begin{array}{l}77.0 \\
(2.2)\end{array}$ & $\begin{array}{l}80.8 \\
(1.1)\end{array}$ & $\begin{array}{l}77.1 \\
(5.7)\end{array}$ & NS & NS & 2.8 \\
\hline Gly & $\begin{array}{l}60.3 \\
(6.6)\end{array}$ & $\begin{array}{l}63.2 \\
(4.4)\end{array}$ & $\begin{array}{l}59.6 \\
(3.4)\end{array}$ & $\begin{array}{l}57.4 \\
(7.3)\end{array}$ & $\begin{array}{l}62.6 \\
(1.7)\end{array}$ & $\begin{array}{l}70.6 \\
(1.8)\end{array}$ & $\begin{array}{l}63.5 \\
(6.0)\end{array}$ & NS & NS & 4.9 \\
\hline His & $\begin{array}{l}70.2 \\
(2.5)\end{array}$ & $\begin{array}{l}73.4 \\
(1.8)\end{array}$ & $\begin{array}{l}70.9 \\
(1.0)\end{array}$ & $\begin{array}{c}69.6 \\
(1.0)\end{array}$ & $\begin{array}{l}72.4 \\
(0.3)\end{array}$ & $\begin{array}{l}74.1 \\
(1.2)\end{array}$ & $\begin{array}{l}80.3 \\
(4.2)\end{array}$ & NS & $* * *$ & 2.2 \\
\hline Ile & $\begin{array}{l}73.6 \\
(1.6)\end{array}$ & $\begin{array}{l}77.7 \\
(1.8)\end{array}$ & $\begin{array}{l}73.6 \\
(1.1)\end{array}$ & $\begin{array}{l}73.2 \\
(1.2)\end{array}$ & $\begin{array}{l}76.0 \\
(0.3)\end{array}$ & $\begin{array}{l}76.2 \\
(1.8)\end{array}$ & $\begin{array}{l}79.3 \\
(4.1)\end{array}$ & NS & $* *$ & 2.1 \\
\hline Leu & $\begin{array}{l}79.2 \\
(1.5)\end{array}$ & $\begin{array}{l}85.1 \\
(1.1)\end{array}$ & $\begin{array}{l}79.9 \\
(0.7)\end{array}$ & $\begin{array}{l}78.6 \\
(0.8)\end{array}$ & $\begin{array}{c}83.0 \\
(1.0)\end{array}$ & $\begin{array}{l}83.6 \\
(0.9)\end{array}$ & $\begin{array}{l}86.6 \\
(3.5)\end{array}$ & NS & $* * *$ & 1.7 \\
\hline Phe & $\begin{array}{l}79.6 \\
(1.3)\end{array}$ & $\begin{array}{l}85.6 \\
(4.7)\end{array}$ & $\begin{array}{l}82.2 \\
(1.7)\end{array}$ & $\begin{array}{l}80.9 \\
(2.5)\end{array}$ & $\begin{array}{l}83.1 \\
(1.9)\end{array}$ & $\begin{array}{l}82.1 \\
(1.4)\end{array}$ & $\begin{array}{l}85.2 \\
(3.0)\end{array}$ & - & - & 2.7 \\
\hline Ser & $\begin{array}{l}73.9 \\
(3.8)\end{array}$ & $\begin{array}{l}78.6 \\
(2.1)\end{array}$ & $\begin{array}{l}75.1 \\
(0.3)\end{array}$ & $\begin{array}{l}75.3 \\
(4.0)\end{array}$ & $\begin{array}{l}77.6 \\
(1.5)\end{array}$ & $\begin{array}{l}74.0 \\
(1.8)\end{array}$ & $\begin{array}{l}80.5 \\
(3.8)\end{array}$ & NS & $*$ & 2.9 \\
\hline Tyr & $\begin{array}{l}83.3 \\
(4.5)\end{array}$ & $\begin{array}{l}84.4 \\
(3.3)\end{array}$ & $\begin{array}{l}82.7 \\
(2.4)\end{array}$ & $\begin{array}{l}81.7 \\
(3.4)\end{array}$ & $\begin{array}{l}85.9 \\
(1.6)\end{array}$ & $\begin{array}{l}81.1 \\
(1.5)\end{array}$ & $\begin{array}{l}83.4 \\
(2.6)\end{array}$ & - & $\cdot$ & 2.9 \\
\hline Val & $\begin{array}{l}69.5 \\
(2.4)\end{array}$ & $\begin{array}{l}74.3 \\
(1.8)\end{array}$ & $\begin{array}{l}72.2 \\
(1.4)\end{array}$ & $\begin{array}{l}70.7 \\
(1.1)\end{array}$ & $\begin{array}{l}74.4 \\
(0.8)\end{array}$ & $\begin{array}{l}71.0 \\
(2.2)\end{array}$ & $\begin{array}{l}75.7 \\
(4.6)\end{array}$ & NS & $*$ & 2.4 \\
\hline
\end{tabular}

1 expressed as percentage units - the following values of basal endogenous losses were used for calculation of SID, g/kg DMI: N 1.145, Lys 0.261, Thr 0.253, Met 0.086, Cys 0.104, Trp 0.081, Ala 0.293, Arg 0.201, Asp 0.413, Glu 0.511, Gly 0.405, His 0.088, Ile 0.193, Leu 0.297, Phe 0.165 , Ser 0.247 , Tyr 0.110 , Val 0.261

2 probability, NS $-\mathrm{P}>0.10,{ }^{*} \mathrm{P}<0.05, * * \mathrm{P}<0.01, * * * \mathrm{P}<0.001$

3 residual standard deviation

4 standard deviation 
Overall, MGF2, MGF5 and MGF7 displayed the highest digestibility values, and MGF1 and MGF4 the lowest. The largest significant differences between batches were observed for tryptophan, $\mathrm{N}$ and cystine $(13.6,13.0$ and 11.2 percentage units, respectively), whereas the smallest significant differences were observed for isoleucine and valine (6.1 and 6.2 percentage units, respectively). In all batches, lysine, threonine, cystine, tryptophan, aspartic acid and glycine were among the least digestible amino acids whereas methionine, arginine, leucine, tyrosine and phenylalanine were among the most digestible ones.

\section{Prediction of standardised ileal digestibility}

None of the analytical criteria were relevant predictors of the SID of threonine, tryptophan, arginine, glutamic acid, glycine and histidine. For the other amino acids, the ratio of N-NDF to total $\mathrm{N}$ concentrations provided the equations with the lowest residual standard deviation and the highest coefficient of determination. The SID of lysine, cystine, alanine, aspartic acid, leucine, phenylalanine and valine decreased significantly $(\mathrm{P}<0.05)$ as the proportion of $\mathrm{N}$ bound to the NDF residue increased. There was a trend $(\mathrm{P}<0.10)$ toward a decrease of SID of $\mathrm{N}$, isoleucine and serine, with the increase in this ratio (Table 5).

Table 5

Prediction of nitrogen and amino acid standardised ileal digestibility (\%) in maize gluten feed according to the ratio of the $\mathrm{N}$ concentration in the NDF residue (N-NDF) to the total $\mathrm{N}$ concentration $(\mathrm{g} / \mathrm{g})$

\begin{tabular}{lccccccc}
\hline & Intercept & s.d. & N-NDF/N & s.d.' & P $^{2}$ & R $^{2}$ & r.s.d. $^{4}$ \\
\hline N & 73.7 & $(3.4)$ & 37.1 & $(17.4)$ & 0.09 & 47.7 & 3.8 \\
Lys & 67.8 & $(1.8)$ & 27.2 & $(9.4)$ & $*$ & 62.9 & 2.1 \\
Met & 89.2 & $(2.1)$ & 24.9 & $(10.5)$ & 0.06 & 52.9 & 2.3 \\
Cys & 73.8 & $(2.9)$ & 39.8 & $(14.9)$ & $*$ & 58.7 & 3.3 \\
Ala & 85.2 & $(1.3)$ & 33.9 & $(6.9)$ & $* *$ & 83.0 & 1.5 \\
Asp & 74.3 & $(1.3)$ & 25.4 & $(6.5)$ & $*$ & 75.4 & 1.4 \\
Ile & 79.0 & $(1.6)$ & 18.7 & $(8.0)$ & 0.07 & 52.5 & 1.8 \\
Leu & 86.9 & $(2.0)$ & 25.8 & $(10.0)$ & $*$ & 57.4 & 2.2 \\
Phe & 86.0 & $(1.3)$ & 18.4 & $(6.8)$ & $*$ & 59.8 & 1.5 \\
Ser & 79.8 & $(1.8)$ & 18.7 & $(9.1)$ & 0.10 & 45.8 & 2.0 \\
Tyr & 85.4 & $(1.1)$ & 12.5 & $(5.8)$ & 0.08 & 48.5 & 1.3 \\
Val & 76.2 & $(1.3)$ & 20.7 & $(6.7)$ & $*$ & 65.9 & 1.5 \\
\hline
\end{tabular}

1 standard deviation

2 probability, ${ }^{*} \mathrm{P}<0.05, * * \mathrm{P}<0.01$

3 coefficient of determination

${ }^{4}$ residual standard deviation 


\section{DISCUSSION}

\section{Composition of $M G F$}

The composition of the batches is in the range reported in the electronic 107 data base $(A F Z, 1998)$ for more than 700 batches of MGF collected in France $(\mathrm{N}=27$ to $42, \mathrm{CF}=47$ to 111 , ash=39 to 103 and $\mathrm{starch}=91$ to $362 \mathrm{~g} / \mathrm{kg} \mathrm{DM})$. The overall absence of correlations between the analytical criteria is probably the result of the variability in the processes implemented during starch extraction, as well as the variability in the level of incorporation of the ingredients (maize steep liquor, envelopes and sometimes maize germ meal), a maize gluten feed is made from. The negative correlation between N-NDF and $\mathrm{N}$ may originate from an increasing level of incorporation of maize steep liquor, rich in $\mathrm{N}$, and, consequently, a decreasing level of incorporation of fibrous residues in the final product. Accordingly, N-NDF is positively correlated with the concentrations of lysine, tryptophan, aspartic acid and glycine, mainly located in the fibrous part of the maize grain, and negatively correlated with glutamic acid, mainly located in the starchy endosperm of maize (Landry and Moureaux, 1980; Chung and Pomeranz, 1985).

\section{Standardised ileal digestibility}

The analysis of the effect of liveweight confirmed that this parameter is of little influence on ileal digestibility of amino acids in growing pigs. This is in accordance with previous demonstration that the end-to-end ileo-rectal anastomosis is appropriate to study ileal digestibility of amino acids in growing pigs, even in the long term (Laplace et al., 1994; Bodin et al., 1998). No obvious explanation appeared for the significant $\mathrm{LWXB}$ interaction observed for phenylalanine and tyrosine. However, it should be considered with care as the effect of the animal, confounded with the effect of liveweight in our experimental design, may have influenced the results.

On average, the SID of $\mathrm{N}$ in MGF was by 19.5 percentage units lower than in maize (Jondreville et al., 2000a). Our SID values were quite low compared with other literature data: with a single batch of $\mathrm{MGF}(\mathrm{CF}=112$ and $\mathrm{N}=39 \mathrm{~g} / \mathrm{kg} \mathrm{DM})$, Mariscal-Landin (1992) calculated that the SID of $\mathrm{N}$ reached $75.9 \%$ and the value reported in the Rhodimet Nutrition Guide (RPAN, 1993) reaches $74 \%$. These authors also reported high SID values for methionine, alanine, arginine, leucine, phenylalanine and tyrosine and low SID values for lysine, threonine, cystine, aspartic acid and glycine. Overall, AA were similarly ranked, regarding their SID, in maize and in MGF (Jondreville et al., 2000a). However, the extent of the difference in SID between maize and MGF differed according to the AA. Overall, the lower the digestibility, the greater the difference: large differences 
were observed for lysine, aspartic acid and glycine (20.5, 18.9 and 20.7 percentage units, respectively), whereas small differences were observed for methionine, arginine, leucine, phenylalanine and tyrosine $(8.7,5.8,10.5,8.8,6.2$ percentage units, respectively).

By calculating SID, no attempt for evaluating the possible influence of the nature of the feedstuff on total endogenous losses was made. The correction of AID for basal endogenous losses only aimed at avoiding the digestibility results to be biased by the dietary level of N and AA (Fan et al., 1994; Sève and Henry, 1996) and at getting additive values of digestible AA supply (Furuya and Kaji, 1991). However, there is evidence that total endogenous losses largely exceed basal endogenous losses. Even corrected for basal endogenous $\mathrm{N}$ losses, ileal $\mathrm{N}$ thus contains variable amounts of specific endogenous $N$, depending on the characteristics of the feedstuff (e.g. De Lange et al., 1990; Grala et al., 1998). Thus, factors affecting either the feed specific endogenous losses, or the undigested dietary fraction, or both, may influence the ranking of AA within a single batch, as well as the differences between the batches.

Dietary fibre may impair SID by encapsulating dietary proteins and limiting their access to digestive enzymes (Green et al., 1987; Leterme et al., 1989; Sève et al., 1994). This phenomenon probably explains the low digestibility of lysine, aspartic acid and glycine, located in the most fibrous part of the maize grain and the high digestibility of leucine, tyrosine and phenylalanine, mainly located in the endosperm fraction of the maize grain. As reported by Sève et al. (1994) and Jondreville et al. (2000b) in wheat milling by-products, the proportion of $\mathrm{N}$ bound to the NDF residue is a relevant predictor for SID of N and most AA in MGF. However, in most cases, this criteria, which may account for the variable level of recovery of dietary AA, explains less than $65 \%$ of the total variability.

Relatively high concentrations of lysine, threonine and particularly tryptophan in the endogenous protein, compared with dietary protein, undoubtedly contributed to their overall low SID in MGF. Many authors reported increasing amounts of $\mathrm{N}$ ileal endogenous losses with increasing amounts of dietary fibre (Sauer et al., 1977; Green et al., 1987; Mariscal-Landin et al., 1995, Schulze et al., 1995). SID was then expected to decrease with the increase in dietary fibre concentration. Such a decrease was observed by Sève et al. (1994) and Jondreville et al. (2000b) in wheat milling by-products. In these studies, the ratio of the dietary ADF or $\mathrm{ADL}$ to AA concentrations were relevant predictors for SID of most AA. The absence of relevance of any of the fibre criteria in the present study may originate from their low variability in MGF: the proportion of N bound to the NDF residue varied by $250 \%$, whereas the ratios of dietary ADF to AA concentration varied roughly by $60 \%$. In wheat milling by-products, the two criteria varied by about $300 \%$ from wheat middlings to wheat bran. It may also be due to either the great variability in the fibre composition of these by-products, or to the lack of rele- 
vance of the classical analytical characterisations we performed for a reliable description of fibre in MGF.

At the end, despite the large variability of the batches of MGF we used, both in terms of industrial origin and of composition, a quite simple criteria (N-NDF) allows to explain part of the variability in SID of most AA. However, further investigations, both for a better characterisation of these feedstuffs and for a better understanding of the factors influencing endogenous losses in pigs fed such byproducts, are required for a more accurate prediction of AA SID.

\section{ACKNOWLEDGEMENT}

The work was performed in collaboration with MENGVOEDER UT-DELFIA (NL), SUOMEN REHU (SF) and SANOFI SANTE NUTRITION ANIMALE (F). The authors wish to thank the staffs of the ITCF pig unit research, laboratory and methods department, as well as of the EUROLYSINE laboratory, for their technical assistance. They gratefully acknowledge B. Sève (Institut National de la Recherche Agronomique, F), R. Pinot (SANOFI SANTE NUTRITION ANIMALE, F), D. Sauvant (Institut National Agronomique de Paris-Grignon, F) and G. Rychen (Ecole Nationale Supérieure d'Agronomie et des Industries Alimentaires, Nancy, F) for their advises in preparing this paper.

\section{References}

AFNOR, 1976. Détermination de la teneur en eau. NF V 03-707. Association Française de Normalisation, Paris-La Défense

AFNOR, 1977a. Dosage de l'azote en vue du calcul de la teneur en protéines brutes. NF V $18-100$. Association Française de Normalisation, Paris-La Défense

AFNOR, 1977b. Dosage des cendres brutes. NF V 18-101. Association Française de Normalisation, Paris-La Défense

AFNOR, 1993a. Aliments des animaux, dosage des acides aminés. NF V 18-113. Association Française de Normalisation, Paris-La Défense

AFNOR, 1993b. Détermination de la cellulose brute, méthode générale. NF V 03-040. Association Française de Normalisation, Paris-La Défense

AFZ, 1998. IO7, Banque de Données de l'Alimentation Animale. Version 4.0, November 1998, Association Française de Zootechnie, Paris

Bodin J.C., McMillan E., Maillard R., van Kempen T., Williams P.E.V., 1998. Effect of time postsurgery on the measurement of ileal digestibility in ileal rectal anastomosed pigs. Proc. Brit. Soc. Anim. Sci., Scarborough (UK), p. 168

Chung O.K., Pomeranz Y., 1985. Amino acids in cereal proteins and protein fractions. In: J. W Finley, D.T. Hopkins (Editors). Digestibility and Amino Acids Availability in Cereals and Oilseeds. American Association of Cereal Chemists. St Paul, Minnesota. pp. 65-107 
De Lange C.F.M., Souffrant W.B., Sauer W.C., 1990. Real ileal protein and amino acid digestibilities in feedstuffs for growing pigs as determined with the ${ }^{15} \mathrm{~N}$-isotope dilution technique. J. Anim. Sci. 68. 409-418

Fan M.Z., Sauer W.C., Hardin R.T., Lien K.A., 1994. Determination of apparent ileal digestibility in pigs: effect of dietary amino acid level. J. Anim. Sci. 72, 2851-2859

Furuya S., Kaji Y., 1991. Additivity of the apparent and true ileal digestible amino acid supply in barlcy, maize, whcat or soya-bean mea! based diets for growing pigs. Anim. Feed Sci. Tech. 32, 321-331

Grala W., Verstegen M.W.A., Jansman A.J.M., Huisman J., van Leeuwen P., 1998. Ileal apparent protein and amino acid digestibilities and endogenous nitrogen losses in pigs fed soybean and rapeseed products. J. Anim. Sci. 76, 557-568

Green S., Bertrand S.L., Duron M.J.C., Maillard R.A., 1987. Digestibility of amino acids in maize, wheat and barley meal measured in pigs with ileo-rectal anastomosis and isolation of the large intestine. J. Sci. Food Agr. 41, 29-43

Jondreville C., van den Broecke J., Gâtel F, Van Cauwenberghe S., 1995. Ileal digestibility of amino acids in feedstuffs for pigs. Eurolysine-ITCF, Paris, pp. 53

Jondreville C., van den Broecke J., Grosjean F., Van Cauwenberghe S., Gâtel F., 2000a. Feeding value of cereals in pigs. 1. Analytical characterisation and ileal true digestibility of amino acids in wheat, triticale, barley, rye, maize and sorghum. Submitted for publication in Anim. Feed Sci. Tech.

Jondreville C., van den Broecke J., Grosjean F., Van Cauwenberghe S., Gâtel F., 2000b. Ileal true digestibility of amino acids in wheat milling by-products for pigs. Ann. Zootech. 49, 1-11

Landry J., Moureaux T., 1980. Distribution and amino acid composition of protein groups located in different histological part of maize grain. J. Agr. Food Chem. 28. 1186-1190

Landry J., Delhaye S., 1992. Simplified procedure for determination of tryptophan of foods and feedstuffs from barytic hydrolysis. J. Agr. Food Chem. 40, 776-779

Laplace J.P., Darcy-Vriilon B., Perez J.M., Henry Y., Giger S., Sauvant D., 1989. Associative effect of feeding different protein-free diets between two fibre sources on ileal and overall digestibilities of amino acids, energy and cell-wall components in growing pigs. Brit. J. Nutr. 61, 75-87

Laplace J.P., Souffrant W.B., Hennig U., Chabeauti E., Février C., 1994. Measurement of precaecal dietary protein and plant cell wall digestion in pigs: comparison of four surgical procedures for ileorcctal anastomosis. Livest. Prod. Sci. 40, 313-328

Leterme P., Thielemans C., Bodart C., Baudart E., Thewis A., 1989. Valeur nutritive et digestibilité apparente iléale et fécale du triticale, du froment et de l'escourgeon chez le porc. Rev. Agr. 42, 305-316

Low A.G., 1982. Digestibility and availability of amino acids from feedstuffs for pigs: a review. Livest. Prod. Sci. 9, 511-520

Mariscal-Landin G., 1992. Facteurs de variation de l'utilisation digestive des acides aminés chez le porc. Ph. D. Thèses. Université de Rennes I, pp. 134

Mariscal-Landin G., Sève B., Colleaux Y., Lebreton Y., 1995. Endogenous amino nitrogen collected from pigs with end-to-end ileorectal anastomosis is affected by the method of estimation and altered by dietary fiber. J. Nutr. 125, 136-146

MINITAB. 1996. MINITAB reference manual (release 11), MINITAB Inc., USA

OJEC, 1980. Dosage de l'amidon-méthode polarimétrique. EEC 3e-72/199 et rectif. Off. J. Eur. Communities

OJEC, 1984. Dosages des matières grasses brutes. EEC 2e-71/393 mod.84/4. Off. J. Eur. Communities

Picard M., Bertrand S., Genin F., Maillard R., 1984. Digestibilité des acides aminés: intérêt de la technique du shunt iléo-rectal chez le porc. Journées Rech. Porcine 16, 355-360 
RPAN 1993. Rhodimet ${ }^{\mathrm{TM}}$ Nutrition Guide. Formulation des aliments en acides aminés digestibles. 2eme Edition. Rhône Poulenc Animal Nutrition, Antony, pp. 54

Sauer W.C., Stothers S.C., Parker R.J., 1977. Apparent availabilities of amino acids in wheat and milling by-products in growing pigs. Can. J. Anim. Sci. 54, 775-784

Schulze H., van Lecuven P., Verstegen M.W.A., van den Berg J.W.O., 1995. Dietary level and source of neutral detergent fiber and ileal endogenous nitrogen flow in pigs. J. Anim. Sci. 73, 441-448

Sève B.. Henry Y., 1996. Protein utilization in non ruminants. In: A.F Nunes, A.V Portugal, J.P. Costa, J.R. Ribeiro (Editors). Proceedings of VIIst Symposium on Protein Metabolism and Nutrition. EAAP Publication No. 81, Vale de Santarem (Portugal), pp. 59-82

Sève B., Mariscal-Landin G.. Février C., Lechevestrier Y., 1994. Prédiction de la digestibilité iléale des acides aminés chez le porc: le cas des issues de blé. Journées Rech. Porcine 26, 259-266

Van Soest P. J., Wine R. H., 1967. Use of detergents in the analysis of fibrous feeds. VI-Determination of plant cell wall constituents. J. AOAC Intern. 50, 50-55

van Soest P.J., Robertson J.B., Lewis A., 1991. Methods for dietary fiber, neutral detergent fiber and non starch polysaccharides in relation to animal nutrition. J. Dairy Sci. 74, 3583-3597

\section{STRESZCZENIE}

\section{Strawność jelitowa aminokwasów glutenu kukurydzianego u świń}

Standardową strawność jelitową (SID) białka i aminokwasów siedmiu partii glutenu kukurydzianego oznaczano na wieprzkach rasy Wielka Biała (LW) lub mieszańcach (LW x Landrace) x (LW x Pictrain) o masie ciała od 42 do $61 \mathrm{~kg}$ z przetokami mostkowymi na końcu jelita biodrowego. Każda partia glutenu byla testowana na 4 zwierzętach.

Wartości SID: lizyny - 62,9; treoniny - 69,6; cystyny - 66,7; tryptofanu - 64,1; kwasu asparaginowego - 69,7 i glicyny - 62,4 wszystkich badanych partii glutenu były najmniejsze. Najlepiej byly trawione: metionina $-84,8$; arginina $-85,6$; leucyna $-82,3$; trypsyna $-83,2$ i fenyloalanina - 82,7. Istotne różnice SID pomiçdzy badanymi partiami glutenu stwierdzono dla większości aminokwasów. SID większości aminokwasów była mniejsza, gdy zwiçkszal się udzial azotu związanego z NDF. 